International Journal of Social Science And Human Research

ISSN(print): 2644-0679, ISSN(online): 2644-0695

Volume 05 Issue 01 January 2022

DOI: $10.47191 / \mathrm{ijsshr} / \mathrm{v} 5-\mathrm{i} 1-38$, Impact factor-5.586

Page No: 284-288

\title{
Synergy of TNI and BNPB in Management Earthquake and Tsunami Disaster in Palu Indonesia
}

\author{
Joni Sulistiawan ${ }^{1}$, Ikhwan Syahtaria ${ }^{2}$, Dohar Siantur ${ }^{3}$, Lukman Yudho Prakoso ${ }^{4}$, Herlina Juni \\ Risma Saragih ${ }^{5}$, Ernalem Bangun ${ }^{6}$ \\ 1,2,3,4,5,6 Republic Indonesia of Defense University, Kawasan IPSC Sentul, Sukahati, Kec. Citeureup, Kabupaten Bogor, Jawa Barat \\ 16810
}

\begin{abstract}
In 2018, a natural disaster occurred in Palu, Central Sulawesi which caused losses both in the number of victims and damage to infrastructure. Natural disasters that occurred in the city of Palu occurred in three types of disasters, namely, earthquakes, tsunamis and liquefaction. The TNI as a form of implementing OMSP TNI, is responsible for being involved in disaster management efforts, together with BNPB. One of the implementing elements of the TNI in carrying out natural disaster management operations is the PRCPB TNI. However, there are still several things that need to be optimized and coordinated from the synergy between the two institutions, namely optimizing the synergy with other ministries/agencies and agencies, the composition of the troops, and the limited facilities and infrastructure. The theory used in analyzing these problems is the theory of synergy, theory of disaster management, role theory, theory of state defense and theory of TNI involvement in Disaster Management. With descriptive qualitative research method, research data were collected through in-depth interviews and documentation studies. Based on the results of the study, the disaster that hit Palu city and several other areas of Central Sulawesi showed that local government authorities also did not fully understand the flow and procedures for dealing with disasters quickly. When a disaster occurs, both the government and the community are not prepared. The government through the BNBP, BPBD, and TNI sent aid personnel in the context of disaster management in Palu City in 2018. In particular, the TNI through PRCPB, several units have sent troops to carry out humanitarian missions according to the mandate of Law Number 3 of 2002 concerning National Defense and Law Number 34 of 2004 about the Indonesian National Army. The synergy between the TNI and various parties from BNPB, BPBD, and the Regional Government in Palu City is going well. However, overlapping tasks in the field, sectoral egos still often occur. The synergy model between the TNI and BNPB is to establish a disaster center so that gaps and problems of command, cooperation, communication and coordination and other problems can be overcome.
\end{abstract}

KEYWORDS: Synergy, BNPB, TNI, Natural Disaster Management, Palu, Indonesia

\section{INTRODUCTION}

Indonesia as one of the countries that has the highest level of natural disaster risk in the world (high risk disaster country), has a position between three world tectonic plates, namely the Indian-Australian oceanic plate, the Pacific oceanic plate, and the Eurasian continental plate. The meeting of three active plates that occurred resulted in Indonesia having complex geological and geomorphological conditions (Dipua, 2021). Geologically, this has an impact on the high potential for tectonic earthquakes, landslides and tsunamis. This is due to the interaction of tectonic plates which can cause tidal waves when they occur in the ocean. Faced with a coastal area that is directly opposite the Indian Ocean and the Pacific Ocean, Indonesian territory has a very high risk of experiencing a tsunami. Indonesia's position is also in the ring of fire with the highest number of active volcanoes in the world (Suhirwan, 2019). There are approximately 80 volcanoes, stretching from west to east. The impact that will occur is very large on the potential for volcanic eruptions and volcanic earthquakes. Indonesia is also experiencing the phenomenon of climate change as a result of global warming which has an impact on extreme climate change. This triggers flooding, flash floods, and erosion in some areas (Aref, 2021).

In the research conducted by the researcher, the research locus will be focused on the occurrence of the 2018 earthquake and tsunami in Palu-Donggala. Damarjati, D. (2018) in his news article informed that on September 28 2018, Palu and Donggala were rocked by an earthquake with a magnitude of 7.4 with the epicenter at a depth of $10 \mathrm{~km}$, the distance is $27 \mathrm{~km}$ northeast of Donggala. Furthermore, the Meteorology, Climatology and Geophysics Agency (BMKG) activated tsunami early warning, alert status for west Donggala coast and alert for northern Donggala, Mamuju, and western Palu City. A tsunami as high as 6 meters with a speed of 800 $\mathrm{km} /$ hour hit Talise Beach, the wave height reached a high billboard near the beach. As of October 20, 2018, the death toll from the earthquake, tsunami and liquefaction in Central Sulawesi reached 2,113 people, of which 1,703 people were in Palu City. A total of 


\section{Synergy of TNI and BNPB in Management Earthquake and Tsunami Disaster in Palu Indonesia}

4,612 people were seriously injured. There were 223,751 people displaced at 122 points. According to BNPB's year-end records, the death toll was updated. The death toll was 2,101 people, 1,727 of them in Palu City, 188 people in Sigi, 171 people in Donggala, 15 people in Parigi Moutong, 1 person in Pasangkayu. The victims lost as many as 1,373 people. There were 4,438 people injured. A total of 221,450 people were displaced. The impact of losses is Rp. 2.89 trillion, the impact of damage is Rp. 15.58 trillion. (Damarjati, D., 2018).

Problems or gaps in the field in the implementation of disaster management carried out by the TNI and BNPB are related to regulations, both Law No. 34 of 2004 and Law No. 24 of 2007 which have not been able to clearly regulate the implementation, cooperation and budget between the two agencies. Furthermore, the capabilities and strength of the TNI and BNPB are still limited, both in terms of human resources, defense equipment, Sarpras and the software they have (Ali, 2021). Besides that, good coordination, communication and cooperation between the TNI and BNPB in the field has not yet been realized, so that sectoral egos appear and seem to work alone. From the problems/gaps above, it is indicated that the synergy between the TNI and BNPB in disaster management has not been implemented properly so that strategic steps are needed to realize a strong and harmonious synergy between the TNI and BNPB. Based on this explanation, this research will observe the synergy between the TNI and BNPB in dealing with the earthquake and tsunami disaster in Palu in order to strengthen the National Defense. Apart from aspects related to disasters, of course the element of synergy in the context of disaster management will be observed regarding the role of the TNI in assisting disaster management activities, especially in Palu in 2018.

\section{THEORY AND METHOD}

Synergy between actors of interest is a very important thing in achieving an organizational goal. Just like public administration science which considers administration as a collaboration between two or more people to achieve goals, synergy is also a combination or combination of elements/parts that can produce better and larger outputs when built properly with the stakeholders in it (Najianti in Rahmawati et al. 2014). Synergy between actors of interest is a very important thing in achieving an organizational goal. Just like public administration science which considers administration as a collaboration between two or more people to achieve goals, synergy is also a combination or combination of elements/parts that can produce better and larger outputs when built properly with the stakeholders in it (Najianti in Rahmawati et al. 2014).

Furthermore, Covey, S.R. (2010) explained that synergy is an activity that complements each other and complements differences to achieve results greater than the number of parts per part. Synergy is a collaboration that can be realized when we can synchronize various alternative desires between team members. Synergy as the ability to create amazing results such as new things or alternatives that didn't exist before. Daft, R. D (2002) describes the occurrence of Synergy as a condition that arises when organizational parts interact with each other to produce a greater combined impact than if done alone by each part. It can be understood that Synergy is a combination of several cores/multiple elements that are combined together to give more and better results than when they work alone.

In this study used a qualitative approach. Sugiono (2012) explains that qualitative research is research whose key instrument lies in the researcher, data collection techniques are triangulation, data analysis is inductive or qualitative. Qualitative research is used to examine the condition of natural objects, and the results of the research emphasize meaning rather than generalization. Qualitative research is also research whose approach explores phenomena that cannot be described using numerical or numeric methods. Furthermore, this research was carried out with a phenomenological approach. Kuswarno, E. (2009) describes that this approach seeks in-depth understanding, and seeks to understand the meaning of events and their relation to people who are in certain situations. Studies with a phenomenological approach attempt to explain the meaning of a number of people's life experiences about a concept or symptom (Kusuma, 2021).

\section{ANALYSIS AND DISCUSSION}

Disaster management requires speed and determination, this greatly affects the success in handling a disaster that occurs suddenly and suddenly. As explained above that preparedness is very much needed in the context of early handling of disasters, it must be admitted that the TNI is the only institution that is able to be mobilized quickly, both personnel and equipment as pioneers when a disaster occurs. However, what happens is that other agencies such as BNPB, BPBD, Regional Government and others are still often constrained by the deployment of personnel and materials and sometimes bureaucracy which often hinders the speed of movement for disaster management. In addition, the accuracy of providing assistance to victims is not well targeted and slow. It is necessary to increase the synergy of all parties, especially the TNI and BNPB, especially to accelerate disaster management. BNPB should coordinate with BPBD after being declared a national/regional disaster emergency status in accordance with their authority, immediately coordinate with the TNI to jointly deploy personnel and equipment as quickly as possible to disaster-affected areas in order to control the situation in the area. As stated by Pressy, Davis and Rimm (Gunarsa, 2003) which states that acceleration is going faster, the process of accelerating, increasing speed or accelerating the rate of change of speed.

Handoko (2003: 196) the need for coordination depends on the nature and need for communication in the implementation of tasks and the degree of interdependence of the various implementing units. This is also confirmed by Handayaningrat (1985:88) 


\section{Synergy of TNI and BNPB in Management Earthquake and Tsunami Disaster in Palu Indonesia}

that coordination and communication are something that cannot be separated. Along with the above statement at the level of coordination and integration in disaster management that has been implemented is still in tatters this is due to the communication system that is not in line besides SOP (standard operating procedure) there is no common standardization among related agencies (Lukman Yudho Prakoso, 2021). Therefore, it is necessary to improve joint SOPs and improve patterns and standards for disaster management nationally which will later be used as guidelines and references for all disaster stakeholders. So that when a disaster occurs, all components of the nation in terms of disaster management use the same standardized SOP and pattern of response, thus communication, coordination and integration as well as a clear line of command to reduce the disaster risk caused

Prijono \& Pranarka (1996: 77) state that empowerment has two meanings. The first understanding is to give power or authority, the second understanding is to give ability to or enable. The meaning of the first understanding includes giving power, transferring power or delegating authority to parties who are less / not yet empowered. On the other hand, the second meaning is to provide ability or empowerment and to provide opportunities for other parties to do something (Suryana; 2010). When a disaster occurs, all national and regional resources can be used or mobilized to support disaster management, in accordance with the above statement that the empowerment of personnel, alpal, sarpras and others owned by all stakeholders is used to complement each other, provide benefits and cover all deficiencies in supporting disaster management. which is hitting (Pramono, 2021). Because so far it is still felt very lacking in the empowerment of existing assets to support the success of disaster management. The TNI and BNPB as the leading sector must be able to make an inventory of all national and regional resource assets owned which can be maximally empowered at any time for disaster management. This needs to be strengthened by the existence of an MoU (memorandum of understanding) with each institution, both government and private, so that there will be no more uncertainty in the mobilization of SDN in the future (Kasih Prihantoro, 2021).

According to (Rachmat, 2004:40) "Partnership is a business cooperation relationship with various parties that is strategic, voluntary, and based on the principles of mutual need, mutual support, and mutual benefit. Partnerships that have been built so far are still very minimal, especially with the private sector, even though the private sector has many capable resources to support the implementation of disaster management, so the role of the private sector is very small, while the private sector actually has great potential. The TNI and BNPB work together to encourage, coordinate and carry out socialization to the private sector regarding the partnership mechanism between state institutions and private parties to jointly face a real enemy, namely a disaster in order to strengthen national defense which is the duty and responsibility of all citizens (Nizar, 2021). To answer and improve the synergy between the TNI and BNPB in disaster management, it is hoped that a more applicable synergy model is needed based on evaluation and suitable ideas and ideas to minimize problems that usually arise in every phase of disaster management (Haris, 2019). With the hope that the efforts that have been described can be realized properly, the model offered is essentially perfecting the synergy that has been formed and established to date (Hasym, 2021). The synergy model is to form an integrated joint organization called the Joint Disaster Training Center (Puslatma Disaster) under the Head of BNPB which in general has the following tasks:

a. Organizing disaster courses and training involving all personnel of the TNI, BNPB and designated government and private ministries/agencies so that improvement in the quality and capability of human resources can be realized.

b. Organizing training for trainers to support course and training operations.

c. Organizing post rehearsals and field rehearsals to test HR capabilities and test joint contingency plans

d. Plan and organize Joint Exercises with foreign countries and disaster comparative studies.

e. $\quad$ Plan, create and evaluate curriculum and syllabus of courses and Exercises

f. Organizing workshops and socialization of disaster preparedness in all regions

g. Prepare, foster and mobilize the SRC PB (Fast Response Unit for Disaster Management) in each province to double the capabilities of the TNI PRCPB or the TNI PB Task Force.

h. Organizing the recruitment of personnel to be trained and fill the SRC PB and the crew of the Joint Disaster Training Center. The Disaster Center was formed to unify attitude patterns, action patterns, similarity to disaster SOPs, capacity building for human resources, communication, coordination and the ability to quickly and accurately mobilize SRC PB staffed by all stakeholder personnel who are trained and equipped with disaster knowledge. It also has the aim that the gap between BNPB and BPBD which initially did not have a line of command can be accommodated by the central disaster center and the provincial disaster center.

\section{CONCLUSION}

Based on the discussion that has been described in previous chapters, it can be concluded as follows:

a. How is the synergy between the TNI and BNPB without neglecting other stakeholders in carrying out the earthquake and tsunami relief in Palu, the TNI sent troops and their defense equipment which are members of the TNI PRCPB which of course cooperates with personnel from BNPB, Central Sulawesi BPBD and other elements. By prioritizing six priority treatments, namely continuing evacuation, searching and rescuing victims, burial of corpses, accelerating the recovery of the electricity network, accelerating fuel procurement, distribution of logistics and food for refugees and accelerating communication networks. The disasters that hit the city of Palu and several other areas of Central 
Sulawesi showed that the local government authorities also did not fully understand the flow and procedures for dealing with disasters quickly. When a disaster occurs, both the government and the community are not prepared.

b. The synergy model between the TNI and BNPB in disaster management is applicable to 3 phases of disaster management, but this has not been implemented optimally because it has not been fully implemented in all regions of the country, for example, in disaster mitigation by way of counseling to deal with disasters in the context of community preparedness, it is only implemented in not all regions. . One of the reasons for this is that there is no line of command between BNPB and BPBD, unlike the TNI which has a clear line of command, thus creating gaps and dissynchronization of central and regional programs. So that disaster management in Palu is still not optimal due to the factors mentioned above. Therefore, it is necessary to take a solution to overcome the above constraints, namely the synergy model between the TNI and BNPB by forming a disaster center organization with assigned tasks. So that the implementation of future disaster management can be carried out comprehensively, effectively and efficiently.

\section{REFERENCES}

1) Ali, I. M., Prakoso, L. Y., \& Sianturi, D. (2021). Marine Defense Strategy in Facing Maritime Security Threats in the Indonesian Sea Territory. Marine Defense Strategy, 6(2), 169-188.

2) Arief Midhio, I Wayan, Risman, Helda, Anwar, Syaiful, and Prakoso, Lukman Yudho, R. (2021). Makassar War in the Perspective of the Indonesian Total War. Journal of Social and Political Sciences, 4(J. Soc. Polit. Sci.), 230-238.

3) Covey, Steven R. 2010. The 7 Habits of Highly Effective People. Tangerang: Binarupa Aksara Publisher.

4) Daft, Richard. 2002. Management, Fifth Edition. Jakarta: Erlangga.

5) Damarjati, D. 2018. Afternoons in Palu and Donggala: Earthquake, Tsunami and Liquefaction. Accessed at

6) https://news.detik.com/berita/d-4361370/sore-dipalu-dan-donggala-gempa-tsunami-dan-likuifaksi on April 19, 2021.

7) Dipua, A., Harahap, N., Puspitawati, D., Aminuddin, F., Prakoso, L. Y., Brawijaya, U., \& Defense, U. (2021). Sea Defense Strategy the Indonesian Navy in Dealing with the South China Sea Conflict. ITALIENISCH, 11(2), $120-126$. https://doi.org/https://doi.org/10.1115/italienisch.v11i2.103

8) Harris, A., Prakoso, L. Y., \& Sianturi, D. (2019). Marine Defense Strategy in the Context of Security Threats in the Indonesian Archipelagic Sea Lanes II. Journal of Social and Political Sciences, Vol.4 No.2 (2021), 5(1), 15-30. https://doi.org/10.31014/aior.1991.04.02.283

9) Hasyim, L. O. M., Prakoso, L. Y., Risman, H., La Ode, M. H., Prakoso, L. Y., \& Risman, H. (2021). War of the Universe (Total War) Strategy for Preventing Terrorism Act (Study in Sultan Hasanuddin International Airport). Sciences, 4(2), 7686. https://doi.org/10.31014/aior.1991.04.02.277

10) Love Prihantoro Zakariya, Lukman Yudho Prakoso, Ratna Damayanti, A. D. (2019). Public Policy Analysis of Defense Areas and Defense Area Plan In Grati Pasuruan. The 3th Indonesia International Defense Science Seminar, 2(University of Defense), 483-490.

11) Kusuma, A. W., Lukman Yudho Prakoso, Sianturi, D., Prakoso, L. Y., \& Sianturi, D. (2021). THE COOPERATION BETWEEN FLEET I COMMAND AND INDONESIAN MARITIME SECURITY AGENCY IN ELIMINATING TRANSNATIONAL CRIME IN THE MALACCA STRAIT. International Journal of Education and Social Science Research, 4(03), 51-61. https://doi.org/: http://dx.doi.org/10.37500/IJESSR.2021.4305

12) Kuswarno, E. (2009). Phenomenological Communication Research Methodology; Conceptions, Guidelines, and Research Examples. Bandung: Widya Padjajaran

13) Lukman Yudho Prakoso, Suhirwan, Kasih Prihantoro, Asep Iwa Soemantri- Editor: Budi Pramono, R. (2021). Marine Defense Policy Teaching Materials (R. Budi Pramono (Ed.); 1st ed.). Defense University Press.

14) Nizar, A. A., Pramono, B., Gunawan, R., \& Prakoso, L. Y. (2021). Handling Social Conflicts in The Context of A Military Campaign Strategy (Study in The Working Area of The Balik Papan Police Resort). International Journal of Social Science And Human Research, 04(05), 1205-1209. https://doi.org/10.47191/ijsshr/v4-i5-40

15) Minister of Defense Regulation No. 6 of 2015 concerning Guidelines for TNI Involvement in Disaster Management.

16) Presidential Regulation No. 8 of 2008 concerning the establishment of the National Disaster Management Agency (BNPB)

17) The Minister of Defense of the Republic of Indonesia No. 19 of 2015 concerning the 2015-2019 National Defense Implementation Policy.

18) Prakoso, L. Y. (2021). Defense Policy Analysis to Deal with Radicalism and Terrorism in Indonesian Universities. Journal of Social and Political Sciences, 4(1).

19) Pramono, B., \& Prakoso, L. Y. (2021). Political Policy for the Papuan Issue in the Context of National Defense. ITALENISCH, 11 (2), 271-275.

20) Rahmawati, Triana et al. (2014) Stakeholder Synergy in Regional Innovation. Journal of Public Administration (JAP) Vol. 2, No. 4, p. 641-647

21) Sugiyono. (2012). Quantitative, Qualitative and R\&D Research Methods. Bandung: Alphabeta 


\section{Synergy of TNI and BNPB in Management Earthquake and Tsunami Disaster in Palu Indonesia}

22) Suhirwan Adryan Ole, Cecep Kurniawan, L. Y. P. (2020). Indonesian Navy Against Covid-19. Public Policy And Administration Research, 10(IISTE), 18-23.

23) Law of the Republic of Indonesia Number 24 of 2007 concerning Disaster Management.

24) Law of the Republic of Indonesia Number 34 of 2004 concerning the TNI. 